\title{
THE MECHANISM OF FORMATION \\ OF AN ASYMMETRIC WAVEGUIDE IN MULTILAYER OBJECTS OF GEOECOSYSTEMS
}

\author{
Kriuchkov A. I., Bakhtyn A. I.
}

\section{INTRODUCTION}

It is known that the process of freezing and thawing is always accompanied by the formation and change of stress and strain fields in the rock massif and the contacting objects of the environment.

To assess the elastic-deformation properties of rocks, methods based on the study of seismic waves are often used, because the acoustic parameters are physically interrelated with the elastic and mechanical.

The main part of the energy of seismic waves propagating from the place of explosion to the protected objects is concentrated in a relatively narrow range of frequency-amplitude spectrum of oscillations. Rock, unfrozen and cryogenic layers define these ranges, forming a certain waveguide in the massif.

Soil freezing, at negative surface temperatures, varies from maximum to zero with a transition to positive temperatures at the appropriate depth. This process requires the establishment of a profile of changes in the velocity and energy of seismic waves depending on the depth, taking into account the temperature, humidity and cracking of the rock massif to ensure the stability of quarries and natural slopes.

The depth of cryogenic layer formation and seismic wave velocity distribution are influenced by ambient temperature, humidity, mineralization and fracture massif, chemical and morphological composition of rocks, presence and height of snow cover, groundwater level, terrain, nature of vegetation, and other factors. 


\section{The problem's prerequisites emergence and the problem's formulation}

Analysis of changes in temperature fields in soils and rocks with depth is presented in modern articles by Chinese scientists ${ }^{1,2}$. In Articles ${ }^{3,4}$, experimental measurements were performed and the regularity of the change in the velocity of seismic waves depending on the thermodynamic parameters of the massif was investigated.

The stability of natural slopes and quarries, at the moment, is devoted to a large number of studies ${ }^{5,6}$. These methods have many advantages, but are not without drawbacks. The main disadvantages are that they do not take into account changes in the thermodynamic parameters of the massif and the nonstationarity of the impulse load.

Given the above, the purpose of the study is to establish the influence of thermodynamic parameters of the massif on the stability of the quarries and natural slopes, as well as the formation of specific conditions for standing waves and fatigue cracks in the waveguide under the action of seismic waves with high energy concentration.

\section{The analysis of existing methods for solving the problem} and formulating a task for the optimal technique development

Seasonal freezing is the process of freezing of the upper layer of rocks with an average annual temperature above $0{ }^{\circ} \mathrm{C}$. Layers of seasonal freezing are underlain by unfrozen and rocks, and their thickness is

${ }^{1}$ Huang R., Huang J., Zhang C., Ma H., Zhuo W., Chen Yi., Zhu D., Wu Q., Mansaray L.R. Soil temperature estimation at different depths, using remotely-sensed data. Journal of Integrative Agriculture. 2020. № 19/1. P. 277-290.

${ }^{2}$ Zhihao C., Shaomin M., Li X., Mingfeng S., Hongchun Q. Causal Research on Soil Temperature and Moisture Content at Different Depths. IEEE Access. 2021. № 9. P. 77-88.

${ }^{3}$ Жуков В.С., Кузьмин Ю.О. Экспериментальные исследования влияния трещиноватости горных пород и модельных материалов на скорость распространения продольной волны. Физика земли. 2020. № 4. С. 39-50.

${ }^{4}$ Wentao L., Hongqing Zh., Yang Ya., Yunlong W., Yuchen F. Study on Low Temperature Mechanical Properties of Rocks under High Strain Rate. Revista de la Facultad de Ingenieria U.C.V. 2016. № 31/5. P. 197-208.

5 Харисов Т.Ф. Проблема оценки коэффициента запаса устойчивости бортов карьера. Проблемы недропользования. 2018. № 3. С. 108-117.

${ }^{6}$ Воробьев А.Е., Нифадьев В.И., Усманов С.Ф. Исследование поведения оползней на основе программного комплекса Landslide Modeller. Весник КГТУ. 2017. № 5. C. 44-49. 
determined by heat exchange, which occurs at negative rock temperatures.

In the case of seasonal freezing of rocks, many aspects of the process of formation and development of the seasonally frozen layer are characterized by qualitative differences. Thus, freezing of such a layer occurs only from above, i.e. there is only one boundary of the section "cryogenic - unfrozen soil". Due to the development of migration processes and phase transitions of moisture in the seasonally frozen layer, migration-segregation layers of ice are formed, there is a vertical compaction of the rock surface, deformations and stresses of subsidence and compaction are recorded. As the freezing front deepens, its rate of advance slows down to a complete stop, which is usually observed in late winter.

The velocity of the fronts during freezing and thawing depends on many factors. The rate of thawing and freezing of the upper layer is determined primarily by the ambient temperature. The faster the temperature rises (or falls) over time and the greater the amplitude of these changes, the faster and deeper the front moves from the surface to the depth of the rocks.

Temperature conditions on the surface of rocks are determined by the conditions of their heat exchange with the atmosphere, and first of all the presence and nature of various insulating coatings (snow, vegetation, artificial coverings), which greatly reduce the amplitude of temperature fluctuations on the rock massif surface ${ }^{7}$.

Features of the cryogenic structure of seasonally frozen and seasonally thawed layers are determined by the composition, structure, thermo-physical and water properties of rocks, initial humidity and nature of its distribution in the massif, depth and groundwater regime in relation to the bottom of the seasonally frozen layer. Also important factors are the nature of the water distribution of the unfrozen layer and their mode, the dynamics of winter freezing and the nature of the temperature regime of cryogenic rocks.

Decreasing the temperature of rocks below $0^{\circ} \mathrm{C}$ leads to the formation of additional fields of stresses and strains in the massif. To reliably estimate the elastic-deformation state in the massif and the objects interacting with it, it is necessary to establish the regularity of the temperature field formation in the depth of the massif and to investigate the change of seismic wave velocity in the depth of the slope or quarry.

${ }^{7}$ Ершов Э.Д. Общая геокриология (Ч. 2). Литогенетическая геокриология. Москва : МГУ, 1995. 386 с. 
In the scientific literature it is accepted to allocate the following basic varieties of the given problem. In 1831, G. Lame and B. Clapeyron formulated the formulation of a one-dimensional problem on the freezing of moist soil and solved a simplified version of it, as a result of additions by $\mathrm{J}$. Stefan. In this case, the formation of cryogenic and unfrozen zones, as well as a mobile freezing front is proposed. It is believed that all phase transitions occur at one temperature, which corresponds to the freezing of rocks ${ }^{8}$.

In the case of fine rocks, the second type of problem can be used, in which phase transitions do not occur on the front of a single stratum, as in the previous statement, but in the region limited by the temperatures of beginning $\theta_{s}$ and end $\theta_{e}$ of phase transformations (Fig. 1, a). The disadvantage of this model is the lack of consideration of the inflow of moisture from the thawed zone to the freezing front and its migration in the frozen zone.

The third model, which takes into account mass transfer, is devoid of this drawback. This type of task is the most difficult. An analytical solution for some simplifications was obtained by I. Zolotar ${ }^{9}$ and G. Feldman ${ }^{10}$. Finding an approximate solution of this problem is also possible by numerical method.

In the article by G. Feldman it is shown that when performing practical calculations, the migration of moisture can be ignored without large losses of accuracy Using this assumption, the problem of change temperature and velocity of seismic waves with the depth of the rock massif is solved in the article. Thus the problem of the second type for forecasting of change of temperature in time with depth of an array in one-dimensional statement is solved.

Тер-Мартиросян 3.Г., Горбачев П.А. Промерзание грунта с учетом переменной температуры на поверхности и фазовых переходов в интервале температур. Вестник МГСУ. 2012. № 1. С. 32-36.

${ }^{9}$ Кудрявцев В.А. Общее мерзловедение. Москва : МГУ, 1978. 456 с.

10 Фельдман Г.М. Методы расчета температурного режима мерзлых грунтов, Москва : Наука, 1973. 254 с. 


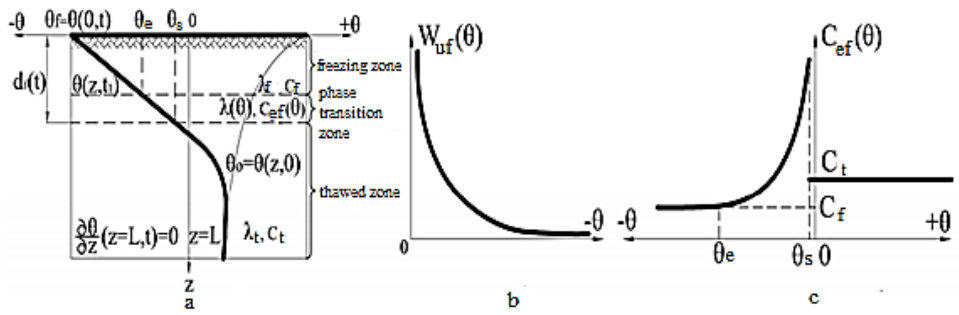

Fig. 1. Calculation scheme of soil freezing temperature problem (a); schemes of temperature dependence $\theta$ on the amount of unfrozen water $W_{u f}(b)$ and heat capacity $C_{e f}(\mathbf{c})$

In the article by Z. Ter-Martirosyan the regularity of temperature distribution $T$ with depth $z$ at the initial moment of time is presented:

$$
\theta_{0}(z, 0)=A_{1}\left(1-\frac{z}{A_{2}}\right)+\left(A_{3}+\frac{A_{4}}{\left(z+A_{5}\right)^{2}+A_{6}}\right),
$$

where $z$ is the current depth coordinate; $A_{1}, A_{2}, A_{3}, A_{4}, A_{5}, A_{6}-$ coefficients obtained on the basis of experimental data.

The dependence of the amount of unfrozen water $W_{u f}$ on the temperature $\theta$ is experimental. For its approximation there are various functions, in this article we will use the dependence offered by L. Chystotynov $^{11}$ (Fig. 1, b):

$$
W_{u f}(\theta)=A+\frac{B}{C-\theta},
$$

where $A, B, C$-coefficients selected on the basis of experimental curves; $\theta$ - temperature.

Based on the results of research on the possibility, without significant loss of accuracy, to neglect the processes of moisture migration to calculate the temperature fields in cryogenic and unfrozen layers of the massif from depth and surface temperature used experimental data obtained by Z. Ter-Martirosyan, presented in Fig. 2.

11 Чистотинов Л.В. Влияние миграции влаги на промерзание грунтов. Сезонное протаивание и промерзание грунтов. Москва : Наука, 1966. С. 77-84. 


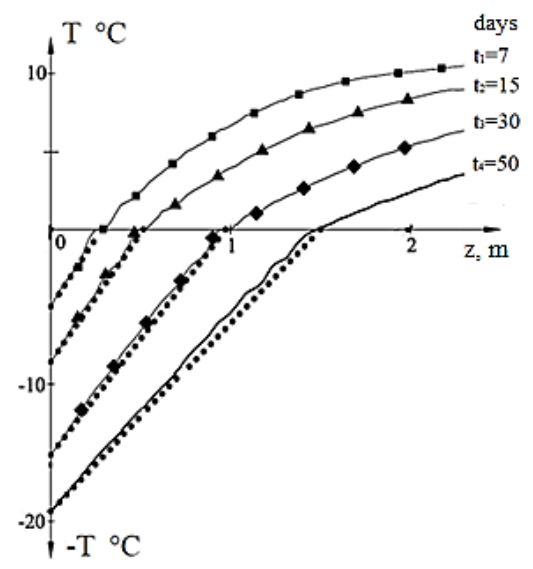

Fig. 2. Change in soil temperature with depth at freezing

Previous studies of the results ${ }^{12,13}$ (Fig. 2) have shown that this dependence can be described as a modified equation 1 :

$$
T_{s}\left(z, T_{a}\right) \approx T_{a}(1-A \cdot z) \text {, at }\left(T_{a}<0^{\circ} \mathrm{C}\right),(0 \leq z<2),
$$

where $T_{s}\left(z, T_{a}\right)$ - soil temperature at depth $z ; z$-depth of soil layer, m; $A$ - temperature coefficient (for Kyiv region $A \approx 1 / 2$ ); $T_{a}$ - ambient temperature, ${ }^{\circ} \mathrm{C}$.

With the onset of moisture crystallization in the soil skeleton, i.e. when the temperature values pass through zero and its subsequent decrease, there is an abrupt increase in the velocity and energy of seismic waves characteristic of all cryogenic rocks. The magnitude of this increase is determined by the type of soil, its humidity, mineralization and cracking.

As the temperature decreases, the risk of destructive energy impact on the lithosphere and protected objects increases significantly.

It is known that the strength and elastic-deformation parameters of rocks depend on the type and velocity of seismic waves. The velocity and energy of seismic waves significantly depend on the thermodynamic

12 Крючков А.І., Бахтин А.І. Закономірність швидкості розповсюдження сейсмічних хвиль в залежності від температури та глибини промерзання грунту. Вісник НТУУ «КПІ». Серія «Гірнищтво». 2017. № 34. С. 5-9

${ }_{13}$ Крючков А.І., Бахтин, А.І. Опис форми, розповсюдження та поглинання вибухового імпульсу в гірському масиві. Сучасні ресурсоенергозберігаючі технологї̈ гірничого виробнищтва. 2019. № 23/1. С. 18-27. 
parameters of the medium. It is established that this dependence persists for the elastic-deformation and strength parameters of the massif.

Given this, the problem of the influence of thermodynamic parameters on the velocity and energy of shock waves in a natural massif, the study of the stability of protected objects, estimating the amount of safe charge mass, choosing a safe design and type of explosives is important, economically feasible and relevant.

To establish the dependence of the velocity of seismic waves on temperature used experimental studies ${ }^{14}$ for saline fine-grained sands at a humidity of $W=10,16,21 \%$ and a fixed value of mineralization of $1 \%$ (Table 1)

Based on previous experimental and analytical studies of changes in the mechanical and acoustic properties of cryogenic rocks, the analysis showed that the dependences in Table. 1 can be represented as follows:

$$
C_{P}(T)=\left(C_{\max }-C_{\text {min }}\right)\left\{\exp \left[-\exp \left(\frac{T-\theta_{C}}{\sigma_{C}}\right)\right]\right\}+C_{\text {nin }},
$$

where $C_{\max }$ - maximum constant value of seismic wave velocity at negative temperatures, $\mathrm{m} / \mathrm{s} ; C_{\min }-$ minimum constant value of seismic wave velocity at positive temperatures, $\mathrm{m} / \mathrm{s} ; T$ - the current value of the rock temperature, ${ }^{\circ} \mathrm{C} ; \theta_{c}-$ the temperature of the maximum intensity of the transition of rocks from the frozen state to the thawed, ${ }^{\circ} \mathrm{C}$ (this dependence parameter that corresponds to the temperature under the condition $\left.\frac{\partial^{2} C_{0}(T)}{\partial T^{2}}=0\right) ; \sigma_{c}$ - determines the temperature ranges of the rock from the frozen state to the thawed, ${ }^{\circ} \mathrm{C}$.

Table 1

Dependence of the velocity of longitudinal seismic waves on the temperature of cryogenic rocks

\begin{tabular}{|c|c|c|c|c|c|c|c|}
\hline$T,{ }^{\circ} \mathrm{C}$ & -20 & -15 & -10 & -5 & -2 & $-0,5$ & 0 \\
\hline \multirow{5}{*}{$C_{p,} \mathrm{~m} / \mathrm{s}$} & \multicolumn{7}{|c|}{ Humidity $W=10 \%$} \\
\cline { 2 - 8 } & 3400 & 3250 & 1600 & 650 & 550 & 500 & 500 \\
\cline { 2 - 8 } & 3800 & 3750 & 2250 & 750 & 650 & 600 & 600 \\
\cline { 2 - 8 } & \multicolumn{8}{|c|}{ Humidity $W=21 \%$} \\
\cline { 2 - 8 } & 4250 & 4200 & 2750 & 1100 & 800 & 700 & 700 \\
\hline
\end{tabular}

${ }^{14}$ Дроговейко И.3. Разрушение мерзлых грунтов взрывом. Москва : Недра, 1981. $244 \mathrm{c}$. 
The calculated parameters for the rock under consideration are given in Table 2.

Table 2

The calculated parameters for the rock under consideration

\begin{tabular}{|c|c|c|c|c|c|}
\hline$T_{a},{ }^{\circ} \mathrm{C}$ & $A$ & $C_{\max } \mathrm{m} / \mathrm{s}$ & $C_{\min } \mathrm{m} / \mathrm{s}$ & $\theta_{c},{ }^{\circ} \mathrm{C}$ & $\sigma_{c},{ }^{\circ} \mathrm{C}$ \\
\hline \multirow{6}{*}{-20} & \multirow{6}{*}{0,5} & \multicolumn{4}{|c|}{ Humidity $W=10 \%$} \\
\hline & & 3400 & 500 & $-9,0$ & $\overline{3,0}$ \\
\hline & & \multicolumn{4}{|c|}{ Humidity $W=16 \%$} \\
\hline & & 3800 & 600 & $-8,4$ & 2,2 \\
\hline & & \multicolumn{4}{|c|}{ Humidity $W=21 \%$} \\
\hline & & 4250 & $\overline{700}$ & $-7,6$ & 2,4 \\
\hline
\end{tabular}

The velocity of seismic waves is significantly affected by the humidity of the rock massif $W$. To study the numerical effect of $W$ on the velocity of seismic waves, it is necessary to establish its effect on all parameters of equation 4. In Fig. 3 shows the dependences of the calculated parameters $C_{\max }, C_{\min }, \theta_{c}, \sigma_{c}$ on $W$.
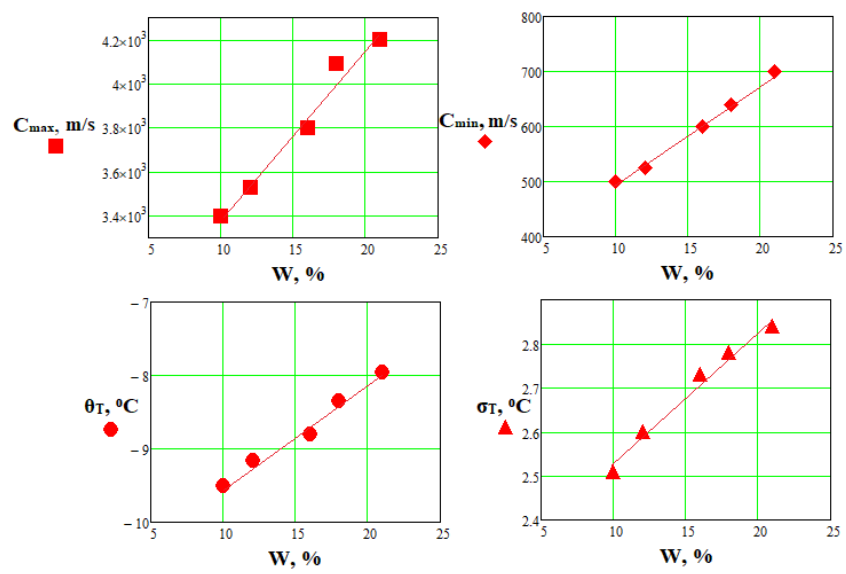

Fig. 3. Dependences of the calculated parameters $C_{\max }, C_{\min }, \theta_{c}, \sigma_{c}$ on $W$

Correlation equations of the dependence of these parameters on the humidity of the massif $W$ are given in Table 3 .

Substituting the correlation equations (Table 3) in the analytical model (equation 4) we obtain a complex dependence of the velocity of seismic waves in cryogenic massifs on the temperature $\mathrm{T}$ and humidity $W$ (Fig. 4): 


$$
\begin{aligned}
& C_{P}(T, W)=[(72.53 W+2663.7)-(18.13 W+315.93)] \times \\
& \times\left\{\exp \left[-\exp \left(\frac{T-(0.143 W-10.94)}{0.03 W+2.22}\right)\right]\right\}+(18.13 W+315.93) .
\end{aligned}
$$

Given that the experimental points lie with a slight deviation on the analytical curve (Fig. 4), we can conclude that the dependence of changes in the velocity of seismic waves from temperature and humidity is described by equation 5 .

The value of the relative calculation error $(\delta)$ according to equation 5 for the considered rock sample at humidity at $W=10,16,21 \%$ is 1.96 , 1.56 and $3.67 \%$, respectively.

The obtained analytical dependence (equations 4 and 5) has the character of a double exponent.

Table 3

Correlation equations of dependences $C_{\max }, C_{\min }, \theta_{c}, \sigma_{c}$ on the humidity of the rock massif $W, \%$

\begin{tabular}{|c|c|}
\hline Parameter name & $\begin{array}{c}\text { Correlation equation } \\
\text { and correlation coefficient }\end{array}$ \\
\hline $\begin{array}{c}\text { Maximum velocity of the } \\
\text { longitudinal seismic wave, } \mathrm{m} / \mathrm{s}\end{array}$ & $C_{\max }=72.53 \cdot W+2663.7$ \\
$R^{2}=0.987$
\end{tabular}

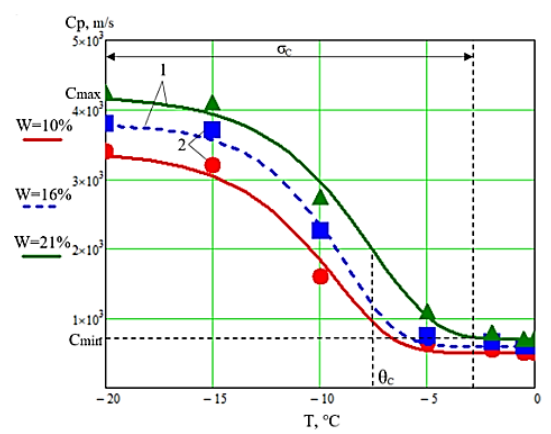

Fig. 4. Analytical dependence of the velocity of propagation of longitudinal seismic waves on the temperature and humidity of the rock massif 1 - analytical curve by equation 4 ;

2 - experimental values of the velocity of longitudinal seismic waves 
For the rock under consideration, a decrease in temperature, below $0^{\circ} \mathrm{C}$ and until the end of the phase transitions of water, leads to an increase in the velocity of seismic waves in 6-7 times. This phenomenon is negative for the environment and the technosphere. In the cold period of the year, the massif is subjected to a much stronger energy load. Given that the energy of a seismic wave quadratically depends on its velocity, at negative temperatures its value increases 35-65 times for different rocks with different values of thermodynamic parameters.

Using equations (3-5), as well as the calculated and correlation parameters (Table 2-3), we obtain the dependence of the change in the speed of longitudinal waves on the depth of soil freezing z (Fig. 5, a):

$$
C_{P}\left(T_{a}, z\right)=\left(C_{\max }-C_{\min }\right)\left\{\exp \left[-\exp \left(\frac{\left(T_{a}(1-A \cdot z)\right)-\theta_{C}}{\sigma_{C}}\right)\right]\right\}+C_{\min },
$$

Using equation 6, only the area $\mathrm{AB}$ is calculated, the area $\mathrm{BC}$ and $\mathrm{CD}$ are approximations based on the known physical and mechanical characteristics of the unfrozen and rock massifs (Fig. 5, a).

The area $A B$ is a cryogenic layer of the massif. In this area of the multilayer massif, the velocity of seismic waves decreases with increasing depth. This is due to the fact that with increasing depth of the cryogenic layer, its temperature increases, as a result of which its modulus of elasticity and contact between the particles of the rock skeleton decrease. With increasing depth, the phase transitions of moisture become less significant, which leads to an increase in the amount of unfrozen water.

Freezing of the upper layer (AB) leads to an increase in its specific acoustic conductivity. This leads to an increase in the flow density of seismic energy, as a result of which more energy is transmitted over long distances with low attenuation. This, in turn, increases the risk of destruction of protected objects at considerable distances from the source of the explosion.

The area BC represents the unfrozen layer of the massif. With increasing depth, the properties of the massif gradually approach the properties of the rock. In this layer, fractures and voids are reduced, the array becomes denser, which leads to an increase in velocity, energy and amplitude of seismic waves.

In the unfrozen layer (BS) conditions are formed for the formation of both traveling and standing seismic waves. The group velocity of such waves is approximately $0 \div 300 \mathrm{~m} / \mathrm{s}$ depending on the physical and mechanical parameters of the massif. Seismic energy is not transferred 
by standing waves to the depth of the array, but is absorbed in local areas where they were formed.

At point $\mathrm{B}$, the temperature of the array is approximately $0{ }^{\circ} \mathrm{C}$ and observed a minimum value of the velocity of seismic waves.

In the area of $\mathrm{CD}$ there is a transition of the massif to the properties of the rock. Point D is the boundary of the two phases "unfrozen layer rock". At this point there are no processes that could affect the change in the speed of seismic waves (change in temperature, humidity or void). The velocity of seismic waves at point $\mathrm{D}$ is constant and depends only on the type, geological and morphological composition of the rock, its density, void and structure. For example, for granite, the velocity of longitudinal seismic waves is approximately $5000 \mathrm{~m} / \mathrm{s}$.

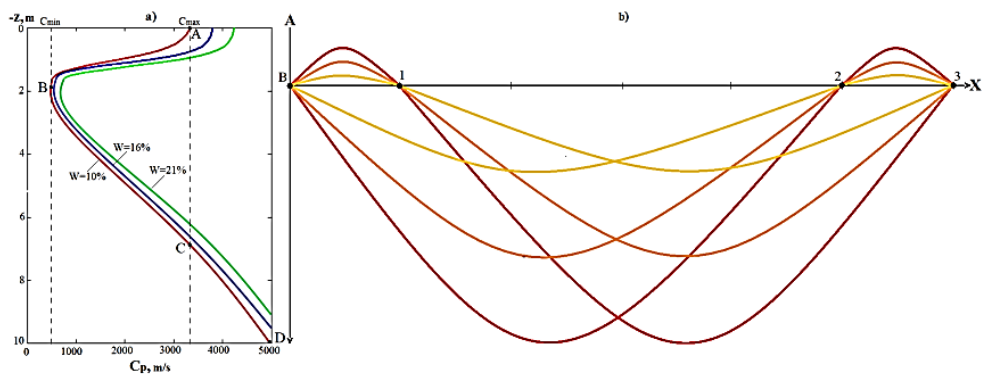

Fig. 5. Profile of the velocity of longitudinal waves along the depth of the massif (a); focusing rays in an asymmetric waveguide (b)

Thus, the multilayer array "cryogenic layer - unfrozen layer - rock" forms a characteristic lenticular profile of the distribution of velocity and energy of seismic waves at depth. This distribution of speed when the slope or quarry freezes in the conditions of explosions, leads to the formation of a specific waveguide. In the conditions of such a waveguide, the rays are reflected, distorted and focused at characteristic points when passing over the entire area of the canal (Fig. 5, b).

Under the conditions of the waveguide, favorable conditions for the formation and occurrence of standing waves increase sharply. A standing wave is a phenomenon of interference of seismic waves that propagate in opposite directions, with energy transfer significantly weakened or absent. A characteristic feature of such waves is the presence of nodes with zero amplitude and antinodes with maximum. In a multilayer cryogenic massif, the positions of antinodes and nodes are unchanged in space. As a result, the 
high energy of the explosion does not propagate in the space of the massif, but is absorbed in local areas where the nodes are formed, which leads to the formation and growth of cracks. Given that the explosive pulse is a nonstationary periodic process, the length of these cracks will increase with each energy flow. Such cracks, the length of which periodically increases with each subsequent impulse, are called fatigue.

In Fig. 6 presents a qualitative scheme of formation of standing seismic waves and fatigue cracks in an asymmetric multilayer waveguide during freezing of the massif.

Despite the fact that the modulus of elasticity of the cryogenic rock grows and has a strengthening character, in the conditions of the waveguide, areas with a high concentration of energy (foci) are formed. In these foci, critical values of tangential (tangential) shear stresses and the formation of planar shear cracks occur (type 2 according to Irwin). Under conditions of periodic explosions, the length of these cracks will gradually increase. After reaching a certain critical value, these cracks will begin to unite to form a sliding plane of the shear prism with a limit stress, which can lead to a classical landslide with all the consequences.

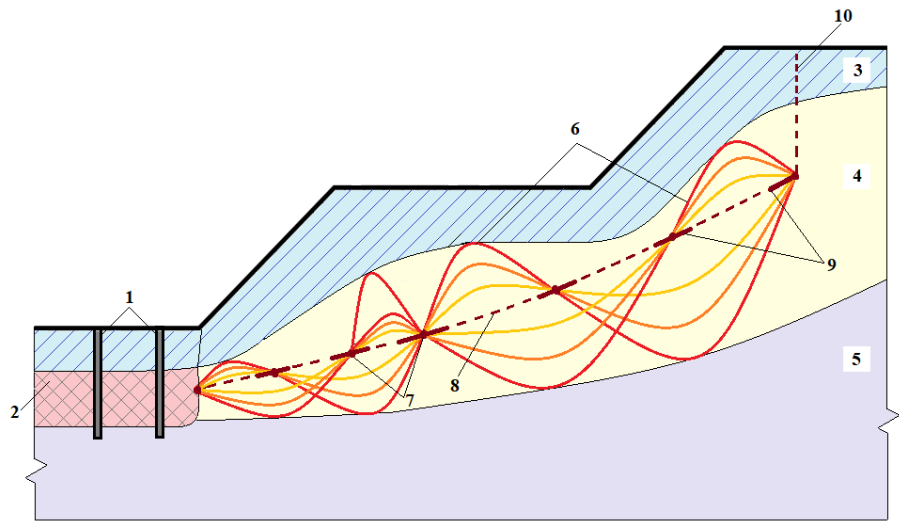

Fig. 6. Formation of an asymmetric waveguide in multilayer objects of geoecosystems

1 - explosive charge; 2 - seismic center of the explosion; 3 - cryogenic layer of soil; 4 - unfrozen layer of soil; 5 - rocks; 6 - the amplitude of oscillations of seismic waves during the explosion; 7 -nodes of oscillating harmonics of seismic waves (minimum amplitude and maximum energy); 8 - the sliding line of the slope landslide prism; 9 - places of intensive formation of shear cracks; 10 - place of formation of a rupture crack 


\section{CONCLUSIONS}

1. It is established that the multilayer cryogenic massif forms specific conditions for the distribution of velocity and energy of seismic waves along the depth of the slope and the quarry (Fig. 6).

2 . The velocity of longitudinal seismic waves in a cryogenic massif is $3000-5000 \mathrm{~m} / \mathrm{s}$, which is 6-8 times faster than the speed of waves in unfrozen rock.

3. This nature of the increase in the velocity and energy of seismic waves is a general pattern that has the character of a double exponent and is experimentally confirmed for different rocks with different thermodynamic parameters.

4. The specific acoustic conductivity increases in the cryogenic upper layer of the soil. This leads to an increase in the energy flux density of seismic waves, as a result of which the wave energy is transmitted over longer distances with less attenuation.

5. In the lower unfrozen layer of soil there are favorable conditions for the formation and development of standing and traveling seismic waves with a group velocity of $0-500 \mathrm{~m} / \mathrm{s}$. Standing waves do not transfer seismic energy to the depth of the massif, and it is absorbed in local places of their formation.

6. With each subsequent explosion, the proportion of standing waves increases, which leads to the formation and periodic development of fatigue cracks in the sliding surface at the points of focus of seismic energy in the soil layer with a temperature close to $0{ }^{\circ} \mathrm{C}$.

7. After some time, the flat shear cracks formed in the shear plane combine, which leads to the formation of a critical stress state of the massif and the development of landslide with all the consequences.

\section{SUMMARY}

Thus, the cryogenic layer of soil (AB), unfrozen layer of soil (BC) and rock layer $(\mathrm{CD})$ create the conditions for the formation of the waveguide and shear surface, which must be taken into account when assessing the stability of slopes.

\section{References}

1. Huang R., Huang J., Zhang C., Ma H., Zhuo W., Chen Yi., Zhu D., Wu Q., Mansaray L.R. Soil temperature estimation at different 
depths, using remotely-sensed data. Journal of Integrative Agriculture. 2020. № 19/1. P. 277-290.

2. Zhihao C., Shaomin M., Li X., Mingfeng S., Hongchun Q. Causal Research on Soil Temperature and Moisture Content at Different Depths. IEEE Access. 2021. № 9. P. 77-88.

3. Жуков В.С., Кузьмин Ю.О. Экспериментальные исследования влияния трещиноватости горных пород и модельных материалов на скорость распространения продольной волны. Физика земли. 2020. № 4. C. 39-50.

4. Wentao L., Hongqing Zh., Yang Ya., Yunlong W., Yuchen F. Study on Low Temperature Mechanical Properties of Rocks under High Strain Rate. Revista de la Facultad de Ingenieria U.C.V. 2016. № 31/5. P. 197-208.

5. Харисов Т.Ф. Проблема оценки коэффициента запаса устойчивости бортов карьера. Проблемы недропользования. 2018. № 3. C. 108-117.

6. Воробьев А.Е., Нифадьев В.И., Усманов С.Ф. Исследование поведения оползней на основе программного комплекса Landslide Modeller. Весник КГТУ. 2017. № 5. С. 44-49.

7. Ершов Э.Д. Общая геокриология (Ч. 2). Литогенетическая геокриология. Москва : МГУ, 1995. 386 с.

8. Тер-Мартиросян 3.Г., Горбачев П.А. Промерзание грунта с учетом переменной температуры на поверхности и фазовых переходов в интервале температур. Вестник МГСУ. 2012. № 1. С. 32-36.

9. Кудрявцев В.А. Общее мерзловедение. Москва : МГУ, $1978.456 \mathrm{c.}$

10.Фельдман Г.М. Методы расчета температурного режима мерзлых грунтов. Москва : Наука, 1973. 254 с.

11. Чистотинов Л.В. Влияние миграции влаги на промерзани грунтов. Сезонное протаивание и промерзание грунтов. Москва : Наука, 1966. С. 77-84.

12.Крючков A.I., Бахтин A.I. Закономірність швидкості розповсюдження сейсмічних хвиль в залежності від температури та глибини промерзання грунту. Вісник НТУУ «КПІ». Серія «Гірництвво». 2017. № 34. С. 5-9.

13.Крючков A.I., Бахтин, А.I. Опис форми, розповсюдження та поглинання вибухового імпульсу в гірському масиві. Сучасні 
ресурсоенергозберігаючі технології гірничого виробництва. 2019. № 23/1. С. 18-27.

14.Дроговейко И.З. Разрушение мерзлых грунтов взрывом. Москва : Недра, 1981. 244 с.

Information about the authors: Kriuchkov Anatolii Ivanovych, $\mathrm{PhD}$, Associate Professor, Head of the Department of Geo-Engineering National Technical University of Ukraine "Igor Sikorsky Kyiv Polytechnic Institute" 37, Peremohy avenue, Kyiv, 03100, Ukraine

Bakhtyn Anatolii Ihorovych, Postgraduate Student at the Department of Ecology and Plant Polymers Technology National Technical University of Ukraine "Igor Sikorsky Kyiv Polytechnic Institute" 37, Peremohy avenue, Kyiv, 03100, Ukraine 